GPJI 3(2) (2019)

\title{
MENINGKATKAN HEALTH-RELATED FITNESS MELALUI WATER FITNESS
}

\author{
Kuston Sultoni ${ }^{1}$, Mustika Fitri ${ }^{2}$, Indah Ayu Puji Lestari ${ }^{3}$, Nurul Fadlillah ${ }^{4}$, Chika \\ Lestari $^{5}$, Risma $^{6}$.
}

Universitas Pendidikan Indonesia

kuston.sultoni@upi.edu

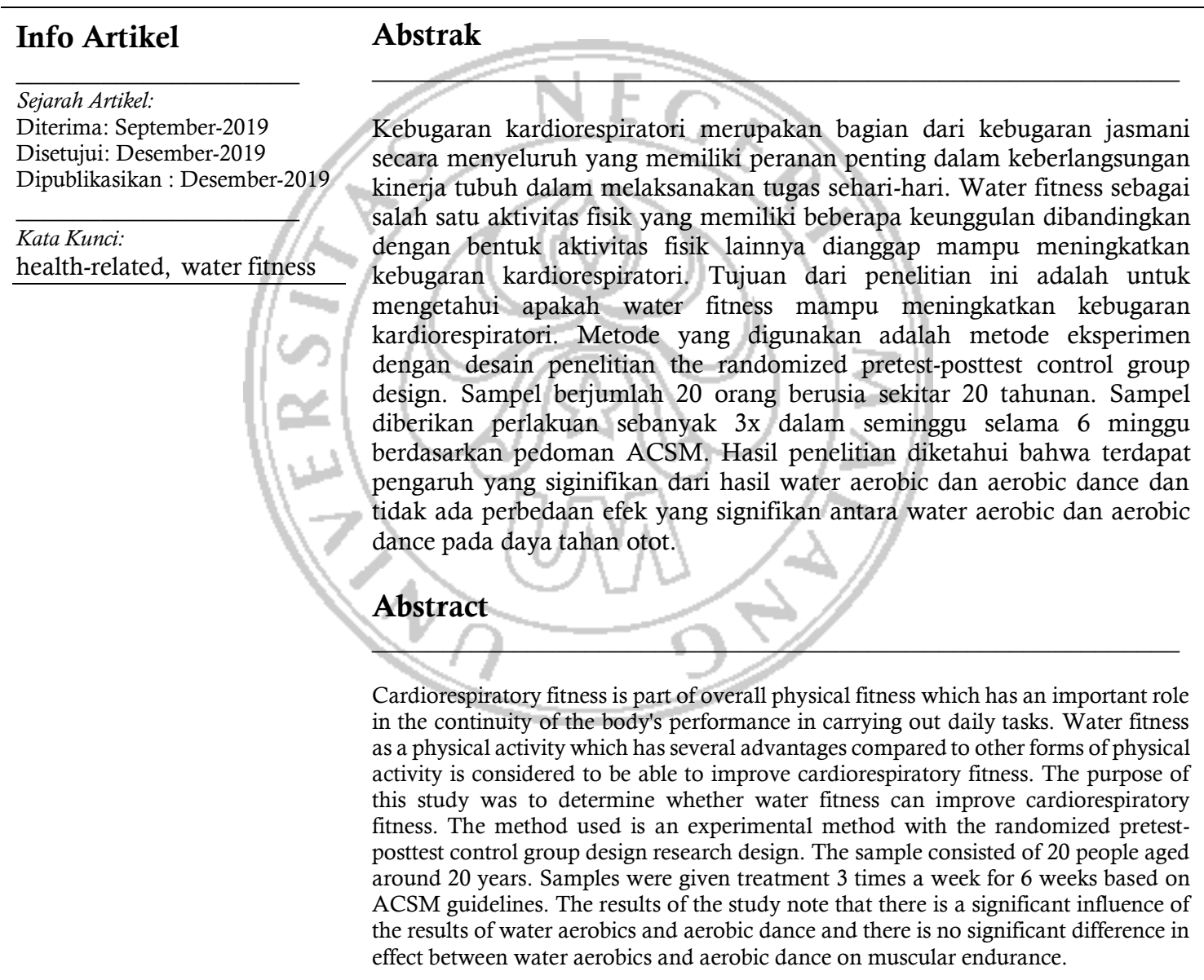

(C) 2019 Universitas Negeri Malang

Alamat korespondensi:

E-mail: pjk.journal@um.ac.id

ISSN: 2614-8293 (Online)

\section{PENDAHULUAN}

Tingkat kebugaran akan semakin menurun dan berat badan akan semakin meningkat oleh karena energi dari makanan yang dikonsumsi setiap hari akan ditimbun sebagai lemak cadangan 
sehingga bisa menyebabkan kegemukan. Kegemukan dan obesitas dapat menimbulkan berbagai macam penyakit, seperti hipertensi dan kolesterol tinggi. Selain itu berkontribusi pada penyakit jantung, hipertensi, diabetes, dan beberapa jenis kanker serta kesulitan psikososial dan psikis (Lee et al., 2013). Selanjutnya, kegemukan dan obesitas akan mengganggu proporsi komposisi tubuh. Komposisi tubuh sendiri salah satunya dipengaruhi oleh jenis aktivitas fisik sehari-hari yang dilakukan dan pola makan yang dikonsumsi.

Kebugaran kardiorespiratori adalah kemampuan sistem peredaran darah dan pernapasan untuk menghasilkan oksigen selama melakukan aktivitas fisik yang berkelanjutan (Rump et al., 2002). Seseorang akan memiliki kebugaran kardiorespiratori yang baik dengan melakukan latihan selama 6 hingga 8 minggu, sehingga denyut jantung istirahat berkurang 10 hingga 20 kali per menit (bpm) dan akan menyelamatkan jantung sekitar 10.483.200 denyut per tahun (Hoeger and Hoeger, 2011). Selain itu keuntungan dari memiliki kebugaran kardiorespiratoi yang baik adalah kemampuan pulih dengan cepat setelah beraktivitas, peningkatan jumlah dan ukuran mitochondria, peningkatan jumlah kapiler fungsional dan peningkatan enzim pembakar lemak.

Kebugaran kardiorespiratori, kekuatan dan daya tahan otot, serta fleksibilitas merupakan bagian komponen kebugaran jasmani. Kekuatan merupakan unsur terpenting dalam tubuh manusia seperti yang dikemukakan oleh (Yane, 2014), kekuatan adalah komponen yang sangat penting guna meningkatkan kondisi fisik seseorang secara keseluruhan. Bukti yang cukup menunjukkan bahwa kemampuan untuk melakukan aktivitas fisik ditentukan oleh kekuatan dan daya tahan otot. Kekuatan otot, daya tahan otot, dan fleksibilitas dipandang sebagai dimensi penting dari kebugaran yang berhubungan dengan kesehatan dan sarana untuk meningkatkan kualitas hidup secara keseluruhan (Kell, Bell and Quinney, 2001).

Jenis aktivitas yang dapat digunakan untuk meningkatkan kebugaran kardiorespiratori antara lain berjalan, joging, bersepeda, aerobik, berenang, latihan kekuatan, dan peregangan (Hoeger and Hoeger, 2009). Selain itu terdapat bentuk aktivitas fisik lain yang menarik untuk dilakukan yakni aerobic dance dimana peserta dapat berolahraga sambil bersosialisasi dan bersenang-senang (Ahmad, Amir and Rosli, 2015). Aerobic dance menjadi tren baru dalam pengembangan olahraga untuk meningkatkan tingkat kinerja seseorang (Yuriy et al., 2014). Aerobic dance yang teratur dapat meningkatkan kebugaran kardiorespirasi (Grimm et al., 2003), membantu mengendalikan berat badan, dan membantu pencegahan penyakit kardiovaskular (Pollock et al., 2018). Banyak peneliti yang meneliti aerobic dance terhadap peningkatan vo2max yaitu, efek aerobik dance pada kemampuan kapasitas kerja fisik, fungsi kardiovaskular dan komposisi tubuh wanita oleh (Dowdy et al., 1985), efek dari aerobik dance pada tingkat kardiovaskular dan berat badan wanita (Ahmad, Amir and Rosli, 2015), perubahan respon kardiorespiratori dan komposisi tubuh dengan melakukan program aerobik dance (Williams and Morton, 1986).

Selain aerobic dance, peneliti-peneliti terdahulu terus mengembangkan jenis aktivitas yang dapat meningkatkan kebugaran kardiorespiratori, salah satunya yaitu aerobik air (water aerobic). Aerobik air adalah salah satu gerakan gerakan aerobik yang dilakukan di air (Madhankumar, 2017). Aerobik di air dapat meningkatkan fleksibilitas tanpa menyebabkan kerusakan pada sendi dan resiko cedera karena efek gravitasi yang berkurang di air, sendi bisa lebih mudah digerakkan dengan lebih leluasa (Palekar, Shah and Kadam, 2018). Aerobik yang dilakukan di air dapat dilakukan oleh semua usia , namun bagi orang dewasa aerobik air ini menjadi alternatif bagi mereka yang tidak menyukai olahraga di darat. Mereka yang mungkin menghindari latihan di darat yaitu mereka yang mengalami sakit punggung bagian bawah selama kehamilan yang diteliti oleh (Granath, Hellgren and Gunnarsson, 2006), selain nyeri punggung bagian bawah , orang yang menghindari latihan di darat yaitu orang yang mengalami masalah pada bagian sendi (Deanna Westby, 2001). Selain itu pelatihan aerobik di air juga berperan penting dalam meningkatkan kebugaran jasmani (Calka, 2010) dan meningkatkan parameter kekuatan (Costa et al., 2018). Berdasarkan pada hasil beberapa penelitian, pennelitian terkiat dengan water aerobic terhadap mahasiswa aktif masih terbatas. Maka dari itu tujuan peneliti yaitu ingin mengetahui apakah aerobic dance dan water fitness selama enam minggu dapat meningkatkan kebugaran kardiorespiratori dan membandingkan jenis aktivitas manakah yang lebih efektif dalam meningkatkan kebugaran kardiorespiratori pada mahasiswa aktif. 


\section{METODE}

\section{Recearch Desain}

Penelitian ini menggunakan metode penelitian eksperimen dimana subjek diberi perlakuan. Design penelitian yang digunakan dalam penelitian ini adalah the randomized pretest-posttest control group design, dimana peserta melakukan pretest untuk mengetahui kebugaran kardiorespiratorinya, lalu di beri pelatihan aerobic dance dan water fitness selama 6 minggu, dan terakhir peserta diberi post test untuk mengetahui hasil akhir dari kebugaran kardiorespiratorinya.

\section{Partisipan}

Subjek dalam penelitian ini yaitu mahasiswa keolahragaan berjumlah 20 orang yang berusia $20 \pm$ tahun yang dibagi menjadi dua kelompok, kelompok I (kelompok eksperimen), kelompok II (kelompok kontrol). Teknik pengambilan sampel yang digunakan yaitu accidental sampling/convenience sampling, dimana kedua sampel dipilih secara random lalu diberikan formulir kesediaan untuk melakukan penelitian.

\section{Instrumen}

Instrumen yang digunakan dalam penelitian ini yaitu menggunakan PACER TEST (Mahar et al., 2011), yaitu melaksanakan lari bolak balik yang berjarak $20 \mathrm{M}$ mengikuti irama music. Dimulai dengan lari pelan-pelan secara bertahap yang semakin lama semakin cepat hingga sampel tidak mampu mengikuti waktu irama lari sesuai dengan irama music.

Penelitian ini menggunakan 3 jenis instrumen untuk mengukur daya tahan otot. Test yang pertama adalah curl up untuk pengukuran daya tahan otot perut, yang kedua test push up untuk pengukuran daya tahan otot lengan (Pescatello, S et al., 2014), dan yang terakhir test wall sit/ wall squat untuk pengukuran daya tahan otot tungkai (Tsai, 2011). Peralatan test curl up yang harus di siapkan adalah dua strip selotip yang ditempatkan di atas lantai berjarak $12 \mathrm{~cm}$. Subjek berbaring dalam posisi terlentang, lutut ditekuk pada sudut $90^{\circ}$ posisi kaki di lantai dan tangan terentang, sehingga ujung jari menyentuh strip terdekat. Ketika subjek mendengarkan instruksi "UP" dari audio, subjek mengangkat badan hingga $30^{\circ}$, tangan harus maju sampai jari-jari subjek menyentuh pita yang kedua. Subjek mulai curl-up ketika mendengar ada aba-aba dari audio speaker dan mengikuti irama dari audio tersebut. Gerakan dihitung setiap kali subjek mencapai posisi yang benar, jika subjek tidak mampu atau teknik tidak tepat dalam dua pengulangan maka diberhentikan (Pescatello, S et al., 2014). Untuk prosedur pelaksanaan test push up diawali dari posisi "turun". Subjek harus mengangkat tubuh dengan meluruskan sikut dan kembali ke posisi "turun", perut tidak boleh menyentuh lantai/ matras. Punggung subjek harus lurus dan harus mendorong ke atas posisi lengan lurus. Subjek memulai pushup ketika ada aba-aba dari audio speaker dan mengikuti irama dari audio tersebut. Penghitungan jumlah push-up secara berurutan tanpa istirahat adalah dihitung sebagai skor. Tes dihentikan jika tidak mampu mempertahankannya teknik yang tepat dalam dua pengulangan (Pescatello, $\mathrm{S}$ et al., 2014). Sedangkan prosedur pelaksaan wallshit dimulai dengan punggung subjek menempel ke dinding, langkahkan kaki ke depan buka kaki dengan selebar bahu. Turunkan tubuh subjek ke bawah, posisi seperti duduk $90^{\circ}$. Jaga punggung tetap rata dengan dinding. Tahan sekuat mungkin dan semaksimal mungkin (Tsai, 2011).

Pada instrument penelitian ini menggunakan test 4 site Skinfold Caliper untuk mengukur tebal lemak tubuh (Nakata et al., 2005) dan mengukur tinggi badan menggunakan stadiometer yang terpasang di dinding tanpa menggunakan sepatu (Deurenberg-Yap, Tan BY, Chew SK, Deurenberg $P, 1999)$. Pengukuran berat badan lebih akurat apabila sampel mengenakan pakaian yang ringan, juga untuk memudahkan pada saat pengukuran. Pada saat pengukuran sampel tidak diperkenankan mengenakan alas kaki (Mcrae et al., 2012). Penilaian Body Mass Index (BMI) dapat di hitung dengan rumus berikut:

$\mathrm{BMI}=$ Berat Badan $(\mathrm{Kg}) /$ Tinggi Badan $(\mathrm{m}) \mathrm{X}$ Tinggi Badan $(\mathrm{m})$

Untuk menentukan lipatan lemak tubuh menggunakan skinfold caliper (Xu et al., 2018). Menurut (Mackenzie, 2005) tes ini hanya membutuhkan empat pengukuran yaitu (biceps, triceps, subscapula, dan suprailiaca) setelah itu catat hasilnya seperti yang terbaca dalam skala kemudian jumlahkan keempat hasil pengukuran.

\section{Treatmen}

Treatment dilakukan 3x dalam seminggu selama 6 minggu berdasarkan pedoman ACSM (Thompson, 2014). Semua subjek diperlakukan sama, baik kelompok kontrol (senam aerobik $n=10$ ) maupun kelompok eksperiment (water aerobic $n=10$ ) pelatihan dilakukan selama 45 menit. Terdiri dari 10 menit pemanasan dengan tempo irama 130-136 Bpm jenis lagu pop, 25 menit inti dengan tempo 142-158 Bpm jenis lagu mix, dan 10 menit terakhir pendinginan dengan tempo 130-136 Bpm 
jenis lagu pop. Untuk mengetahui denyut jantung, semua sample memakai Polar Heart rate monitor pada pertemuan pertama ke enam dan ke-12.

Untuk program latihan water aerobic diawali dengan pemanasan jalan di tempat didalam air, setelah itu melakukan gerakan mulai dari bagian kepala, bagian lengan, bagian pinggang dan bagian kaki, pemanasan gerakan ini dilakukan dalam 10 menit. Lalu masuk kedalam latihan inti dengan durasi waktu 25 menit bagian lengan melakukan gerakan seperti meninju, scissoring, butterfly. Untuk bagian kaki seperti jogging di tempat, menendang kaki lurus, mengangkat lutut tinggi, dan berbagai bentuk lompatan kecil. Terakhir gerakan yang di lakukan adalah pendinginan 10 menit gerakan hampir sama dnegan pemanasan. Untuk memantau intensitas 60\%-85\% Denyut Nadi Maksimal penelitian ini menggunakan POLAR heart rate monitor.

Sedangkan program latihan senam aerobik gerakanya hampir sama dengan water aerobic hanya senam aerobik dilakukan di darat. Gerakan yang dilakukan seperti marching, jogging, kicking, single step, double step, gripevire, leg curl, heel touch. Untuk durasi waktunya pun sama seperti water aerobik.

\section{Statistical Analysis}

Statistic analisis yang digunakan dalam penelitian ini yaitu uji paired sample $t$ test dilihat dari pretest dan posttest, independent sample t test di dapat dari nilai gain score dimana hasil gain score didapat dari nilai posttest dikurangi pretest.

HASIL

Berdasarkan hasil posttest dengan sampel 20 orang yang dibagi menjadi 2 kelompok, kelompok I (kelompok water aerobik) dan kelompok II (kelompok aerobic dance) di peroleh hasil data sebagai berikut :

Tabel 1. Rata-rata, Simpangan Baku dan Hasil perhitungan statistika inferensial Komponen Health-Related Fitness Sebelum dan Sesudah Pemberian Treatmen

\begin{tabular}{|c|c|c|c|c|c|c|c|c|c|}
\hline \multirow[t]{2}{*}{ Variabel } & \multirow[t]{2}{*}{ Group } & \multirow{2}{*}{8} & \multicolumn{4}{|c|}{ Pretest $\quad$ Posttest } & \multirow{2}{*}{$\begin{array}{l}\text { Paired } \\
\text { sample } \quad t \\
\text { test (Sig) }\end{array}$} & & \multirow{2}{*}{$\begin{array}{l}\text { Independent } \\
\text { Sample t-test } \\
\text { (sig) }\end{array}$} \\
\hline & & & Mean & Stdev & Mean & Stdev & & $\mathrm{t}-$ & \\
\hline Vo2max & $\begin{array}{l}\text { Water } \\
\text { Aerobi }\end{array}$ & $\begin{array}{l}\text { aerobic } \\
\text { c dance }\end{array}$ & $\begin{array}{l}37,87 \\
39,61\end{array}$ & $\begin{array}{l}1,76 \\
1,75\end{array}$ & $\begin{array}{l}38,78 \\
41,02\end{array}$ & $\begin{array}{l}1,76 \\
1,88\end{array}$ & $\begin{array}{l}0,000^{* *} \\
0,000^{* *}\end{array}$ & & $0,000^{\star *}$ \\
\hline Push-Up & $\begin{array}{l}\text { Water } \\
\text { Aeroic }\end{array}$ & $\begin{array}{l}\text { Aerobic } \\
\text { Dance }\end{array}$ & $\begin{array}{l}12,90 \\
9,30\end{array}$ & $\begin{array}{l}6,154 \\
3,164\end{array}$ & $\begin{array}{l}17,20 \\
13,90\end{array}$ & $\begin{array}{l}5,266 \\
4,999\end{array}$ & $\begin{array}{l}0,000^{* *} \\
0,005^{* *}\end{array}$ & & 0,455 \\
\hline Curl-Up & $\begin{array}{l}\text { Water } \\
\text { Aeroic }\end{array}$ & & $\begin{array}{l}24,70 \\
24,50\end{array}$ & $\begin{array}{l}7,424 \\
5,662\end{array}$ & $\begin{array}{l}28,90 \\
28,20\end{array}$ & $\begin{array}{l}7,894 \\
4,417\end{array}$ & $\begin{array}{l}0,000^{* *} \\
0,006^{* *}\end{array}$ & & 0,832 \\
\hline Wall-Sit & $\begin{array}{l}\text { Water } \\
\text { Aeroic }\end{array}$ & $\begin{array}{l}\text { Aerobic } \\
\text { Dance }\end{array}$ & $\begin{array}{l}59,10 \\
63,10\end{array}$ & $\frac{18,077}{30,556}$ & $\begin{array}{l}83,60 \\
93,10\end{array}$ & $\begin{array}{l}19,051 \\
38,854\end{array}$ & $\begin{array}{l}0,005^{* *} \\
0,016^{*}\end{array}$ & & 0,658 \\
\hline BMI & $\begin{array}{l}\text { Water } \\
\text { Aeroic }\end{array}$ & $\begin{array}{l}\text { Aerobic } \\
\text { Dance }\end{array}$ & $\begin{array}{l}24,60 \\
23,11\end{array}$ & $\begin{array}{l}2,608 \\
1,840\end{array}$ & $\begin{array}{l}24,27 \\
22,74\end{array}$ & $\begin{array}{l}2,705 \\
1,691\end{array}$ & $\begin{array}{l}0,002^{* *} \\
0,024^{*}\end{array}$ & & 0,189 \\
\hline $\begin{array}{l}\text { Fat } \\
\text { Percentage }\end{array}$ & $\begin{array}{l}\text { Water } \\
\text { Aeroic }\end{array}$ & $\begin{array}{l}\text { Aerobic } \\
\text { Dance }\end{array}$ & $\begin{array}{l}28,92 \\
28,15\end{array}$ & $\begin{array}{l}2,073 \\
1,443\end{array}$ & $\begin{array}{l}25,95 \\
23,05\end{array}$ & $\begin{array}{l}2,811 \\
3,177\end{array}$ & $\begin{array}{l}0,000^{* *} \\
0,002^{* *}\end{array}$ & & 0,857 \\
\hline
\end{tabular}

Keterangan:

*signifikan $<0,05$

${ }^{* *}$ signifikan $<0,01$

Nilai rata-rata kelompok water aerobic ketika pretest yaitu 37,87 dengan std. deviation 1,76 kemudian setelah diberi program latihan water aerobic rata-rata nya menjadi 38,78 dengan std. deviation 1,76. Untuk kelompok aerobik dance pada saat pretest nilai rata-ratanya 39,61 dengan std. deviation 1,75. Dan setelah diberi program aerobik dance rata-rata nya menjadi 41,02 dengan Std. Deviation 1,88 . Kemudian secara statistik terdapat peebedaan yang signifikan antara pretest dan posttest, dimana nilai posttest lebih meningkat. Dan setelah dibandingkan antara aerobic dance dan water aerobic, menyatakan bahwa untuk meningkatkan kebugaran kardiorespiratori program latihan 
aerobic dance lebih efektif dalam meningkatkan kebugaran kardiorespiratori. Nilai pretest ketlompok water aerobic yaitu 37,87 setelah di beri pelatihan, signifikan meningkat menjadi 38,78. Pada kelompok aerobic dance nilai rata rata dalam pretest yaitu 39,61, signifikan meningkat menjadi 41,02 setelah diberi pelatihan.

Berdasarkan Tabel 1 hasil skor awal push up water aerobic ketika pretest hasil mean 12,90 dengan std.deviasi 6,154 , setelah diberikan perlakuan hasil skor push up pada saat postest hasil mean 17,20 dengan std.deviasi 5,266 dan terdapat perbedaan yang signifikan dengan hasil paired sampel $t$ test $p=0,000$. Sedangkan pada kelompok aerobic dance hasil push up pretest mean 9,30 dengan std.deviasi 3,164, untuk hasil post test push up mean 13,90 dengan std.deviasi 4,999 dan terdapat perbedaan yang signifikan dengan hasil paired sampel $t$ test $p=0,005$. Ketika hasil water aerobic dan aerobic dance dibandingkan dengan hasil independent smpel $t$ test terdapat hasil $p=0,455$ maka data tersebut tidak terdapat perbedaan yang siginifikan.

Hasil skor awal curl up water aerobic ketika pretest hasil mean 24,70 dengan std.deviasi 7,424, setelah diberikan perlakuan hasil skor curl up pada saat post test hasil mean 28,90 dengan std.deviasi 7,894 dan terdapat perbedaan yang signifikan dengan hasil paired sampel t test $p=0,000$. Sedangkan pada kelompok aerobic dance hasil curl up pretest mean 24,50 dengan std.deviasi 5,662, untuk hasil post test curl up mean 28,20 dengan std.deviasi 4,417 dan terdapat perbedaan yang signifikan dengan hasil paired sampel t test $p=0,006$. Ketika hasil water aerobic dan aerobic dance dibandingkan dengan hasil independent smpel $t$ test terdapat hasil $p=0,832$ maka data tersebut tidak terdapat perbedaan yang siginifikan.

Hasil skor awal wallsit water aerobic ketika pretest hasil mean 59,10 dengan std.deviasi 18,077, setelah diberikan perlakuan hasil skor wallsit pada saat postest hasil mean 83,60 dengan std.deviasi 19,051 dan terdapat perbedaan yang signifikan dengan hasil paired sampel $t$ test $p=0,005$. Sedangkan pada kelompok aerobic dance hasil wallsit pretest mean 63,10 dengan std.deviasi 30,556, untuk hasil post test wallsit mean 93,10 dengan std.deviasi 38,854 dan terdapat perbedaan yang signifikan dengan hasil paired sampel t test $p=0,016$. Ketika hasil water aerobic dan aerobic dance dibandingkan dengan hasil independent smpel t test terdapat hasil $p=0,658$ maka data tersebut tidak terdapat perbedaan yang siginifikan.

Analisis komposisi tubuh pada kelompok eksperimen diperoleh nilai pretest imt water erobic dengan nilai mean $=24.6000$ dan nilai standar deviasi $=2.60895$, untuk nilai posttest imt water aerobic mean $=24.2700$ dengan nilai standar deviasi $=2.70516$. Untuk hasil imt aerobic dance diperoleh niai mean $=23.1100$ dan standar deviasi 1.84056 , untuk nilai posttest imt aerobic dance diperoleh jasil mean $=22.7400$ dan nilai standar deviasi $=1.69194$. Hasil body fat water aerobic nilai mean $=28.9200$ dengan nilai standar deviasi $=2.07353$, untuk nilai posttest body fat water aerobic diperoleh nilai mean $=25.9500$ dan standar deviasi $=2.1118$. Untuk hasil body fat aerobic dance diperoleh nilai mean $=28.1500$ dengan standar deviasi $=1.44318$, untuk nilai posttest body fat aerobic dance diperoleh nilai mean $=23.0500$, dan standar deviasi $=3.17743$.

Dari tabel diatas diperoleh nilai paired sampel t-test pada imt water aerobic sebesar $.002<0.05$ maka data tersebut signifikan dan imt aerobic dance $.024 .<0.05$ maka data tersebut signifikan. Dari tabel diatas diperoleh nilai body fat water aerobic sebesar $.000<0.05$ maka data tersebut dikatakan signifikan, dan body fat aerobic dance sebesar $.002<0.05$ maka data tersebut signifikan. Berdasarkan hasil pengolahan data terdapat nilai independent sampel t-test pada indeks massa tubuh sebesar $0.189>0.05$ maka data tersebut tidak signifikan, dengan nilai body fat sebesar $0.857>0.05$ maka data tersebut tidak signifikan.

\section{PEMBAHASAN}

Seperti yang disebutkan, bahwa untuk meningkatkan kebugaran kardiorespiratori dapat meningkat dengan melakukan olahraga dengan intensitas, frekuensi, dan durasi yang cukup, dimana intensitas yang harus dilakukan untuk meningkatkan kebugaran kardiorespiratori yaitu 50\%-85\% dari DNM (Gaesser \& Rich, 1984, Burke \& Franks, 1975), dengan frekuensi 3-5 kali perminggu (Wenger and Bell, 1986) dan durasi waktu $15-25$ menit (Burke and Franks, 1975). Sehingga baik aerobic dance maupun water fitness menghasilkan peningkatan yang signifikan dalam peningkatan kebugaran kardiorespiratori. Namun, hasil perbandingan dalam penelitian ini dinyatakan bahwa aerobic dance lebih efektif peningkatannya daripada water fitness, dan dapat disimpulkan bahwa aerobic dance lebih efektif dalam peningkatan kebugaran kardiorespiratori di banding water fitness. 
Water fitness yaitu jenis aktivitas fisik yang telah ada namun banyak masyarakat yang belum mengetahui terhadap jenis aktivitas ini, padahal sudah banyak peneliti yang meneliti tentang water fitness, contohnya pada penelitian yang dilakukan (Chu et al., 2004) menggunakan program latihan water fitness selama 8 minggu dan signifikan meningkat kebugaran jasmaninya. Penelitian selanjutnya yang meneliti mengenai aerobik air yaitu (Grimm et al., 2003) melakukan penelitian menggunakan water aerobic selama 7 minggu kepada mahasiswa wanita yang menghasilkan peningkatan yang signifikan terhadap kebugaran kardiovaskularnya. Namun pada penelitian (Alegre, 2013) tidak ada perubahan kapasitas aerobik dalam pelaksanaan latihan aerobik air selama 24 minggu, hal ini menimbulkan keraguan kepada peneliti. Setelah peneliti melakukan penelitian ditemukan hasil bahwa water fitness meningkatkan kebugaran kardiorespiratori.

Aerobic dance kian hari kian populer, dan banyak masyarakat yang sudah tidak asing lagi terhadap aerobic dance, banyak juga peneliti peneliti yang telah meneliti aerobic dance, salah satu contoh (Mehrtash et al., 2015) melakukan penelitian aerobic dance untuk meningkatkan kemampuan motorik anak dan kapasitas aerobik anak usia 10-13 tahun dan hasilnya menghasilkan perubahan positif dalam kemampuan motorik anak usia 10-13 tahun. (Helgerud et al., 2007) menyatakan bahwa dengan latihan aerobic dance dapat meningkatkan kapasitas aerobik secara signifikan. Dan (Dowdy et al., 1985) menghasilkan hasil yang signifikan terhadap vo2max pada masa pelatihan aerobic dance selama 10 minggu. Dari hasil rujukan diatas selaras dengan hasil penelitian peneliti bahwa aerobic dance terbukti dapat meningkatkan kebugaran kardiorespiratori (vo2max).

Ada pula hasil penelitian-penelitian pengaruh water aerobic dan aerobic dance yang sependapat dikemukakan, Menurut Dinata, 2007 "Yang mempengaruhi komponen kondisi fisik utama pada cabang olahraga aerobic dance diantaranya daya tahan otot jantung, daya tahan otot lengan, daya tahan otot perut, dan kelentukan". Pelatihan aerobic dance dapat meningkatkan fleksibilitas, eksplosif / statis kekuatan, daya tahan otot, kecepatan dan parameter keseimbangan (Trajković et al., 2016).

Beberapa hasil dari penelitian water aerobic mereka sependapat bahwa "Aerobik air telah meningkat pesat di masyarakat dalam beberapa tahun terakhir sejak itu terbukti memberikan manfaat yang sama diistilah kebugaran fisik sebagai pelatihan berbasis darat program, memiliki keuntungan yang menghasilkan sedikit dampak peningkatan pada tungkai bawah" (Pinto, 2011). Selain itu, olahraga air meningkatkan ketahanan pernapasan kardiovaskular, kekuatan, daya tahan otot dan fleksibilitas (Liu et al., 2011). Senam aerobik air selama 12 minggu akan meningkatkan daya ledak, daya tahan kekuatan tungkai atas dan kebugaran kardiorespirasi keseluruhan (Benelli, Ditroilo and De Vito, 2004). Latihan akuatik secara signifikan meningkatkan tungkai kekuatan otot (Wang et al., 2007). Namun ada pula yg berbeda pendapat penelitian yang berjudul "Dampak Aquatiq Dua Puluh Empat Minggu Program Pelatihan Kekuatan Otot Dalam Perempuan Sehat" dengan relawan berpartisipasi dalam latihan air dangkal selama 60 menit sehari, 3 hari seminggu. Program latihan terdiri dari pemanasan 10 menit dan peregangan, 25 menit olahraga tipe-daya tahan (menari) dengan detak jantung (HR) , 20 menit latihan daya tahan tubuh bagian atas dan bawah. Namun, dilaporkan bahwa program yang digunakan adalah tidak cukup spesifik untuk menyebabkan peningkatan pada otot kekuatan, fleksibilitas, atau komposisi tubuh(Tsourlou T, Benik A, Dipla K, Zafeiridis A, 2006).

Perbedaan Pengaruh Senam Aerobik dan Water Aerobic Terhadap Daya Tahan Otot. Berdasarkan hasil dari pengolahan dan analisis data yang telah dilakukan dari dua kelompok aktivitas fisik water aerobik dan senam aerobik sebagai peneliti mendapatkan penemuan yaitu bahwa aktivitas fisik water aerobic dapat memberikan pengaruh secara signifikan terhadap peningkatan daya tahan otot. Peneliti melakukan perbandingan aktivitas fisik water aerobic dan senam aerobik karena didalam penerapannya kedua aktivitas fisik ini terdapat perbedaan yaitu dalam aktivitas fisik water aerobic dilakukan di dalam air dengan ketinggian sepinggang sampai sedada, gerakannya pun hampir sama sementara dalam aktivitas fisik senam aerobik dilakukan di darat. Dalam penerapannya aktivitas fisik water aerobic dan senam aerobik dapat meningkatkan daya tahan otot, sesuai dengan deskripsi yang telah dijelaskan daya tahan otot meningkat untuk kelompok eksperimen (water aerobic) dan kelompok kontrol (senam aerobik) meningkat juga.

\section{KESIMPULAN}

Berdasarkan pada analisis data dan pembahasan hasil, diketahui bahwa terdapat pengaruh yang signifikan dari hasil jenis latihan water fitness maupun aerobic dance dalam data pre test dan post test. Hasil selanjutnya ditemukan bahwa terdapat perbedaan signifikan peningkatan VO2max 
dari kedua kelompok dimana senam aerobic lebih efektif dalam peningkatan kebugaran kardiorespiratori dibandingkan dengan water fitness. Water aerobic dapat digunakan sebagai program peningkatan $\mathrm{VO} 2 \mathrm{max}$, namun tidak lebih efektif ketika dibandingkan dengan aerobic dance di darat.

Hasil penelitian ini menyimpulkan bahwa terdapat pengaruh yang siginifikan dari hasil water aerobic dan aerobic dance. Jika dibandingkan perbedaan pengaruh anatara water aerobic dan aerobic dance terhadap daya tahan otot maka dapat disimpulkan, bahwa tidak ada perbedaan efek yang signifikan antara water aerobic dan aerobic dance pada daya tahan otot. Meskipun demikian hasil ini menunjukkan bahwa 6 minggu latihan water aerobic dalam air tiga kali seminggu tampaknya lebih bermanfaat dan lebih efektif untuk daya tahan otot lengan dan daya tahan otot perut, sedangkan untuk daya tahan otot tungkai lebih efektif aerobic dance.

Berdasarkan hasil pengolahan data dan analisis data yang telah dilakukan dalam penelitian ini terdapat pengaruh yang signifikan meningkat yang artinya aerobic dance berpengaruh terhadap Indeks Massa Tubuh dan Presentase Lemak, karena aktifitas fisik yang dilakukan secara rutin akan mempengaruhi komposisi tubuh. Dari hasil data pengaruh water aerobic terhadap IMT dan Presentase Lemak terdapat perubahan penurunan berat badan dan lemak tubuh sama halnya dengan olahraga aerobic lainnya yang mempunyai berbagai manfaat salah satunya untuk membentuk tubuh yang ideal. Hasil selanjutnya tidak terdapat perbedaan antara keduanya karena aerobic dance dan water aerobic efektif untuk menurunkan komposisi tubuh.

\section{DAFTAR PUSTAKA}

Ahmad, M. F., Amir, M. and Rosli, A. (2015) 'Effects of Aerobic Dance on Cardiovascular Level and Body Weight among Women', 9(12), pp. 874-882.

Alegre, P. (2013) 'MAXIMAL/AND VENTILATORY THRESHOLDS OF OXYGEN UPTAKE AND RATING OF PERCEIVED EXERTION RESPONSES TO WATER AEROBIC EXERCISES', 27(7), pp. 1897-1903.

Benelli, P., Ditroilo, M. and De Vito, G. (2004)'PHYSIOLOGICAL RESPONSES TO FITNESS ACTIVITIES: ACOMPARISON BETWEEN LAND-BASED AND WATER AEROBICS EXERCISE', Journal of Strength and Conditioning Research, 18(4), pp. 719-722.

Burke, E. J. and Franks, B. D. (1975) 'Changes in VO2 max resulting from bicycle training at different intensities holding total mechanical work constant', Research Quarterly. American Alliance for Health, Physical Education and Recreation. Taylor \& Francis, 46(1), pp. 31-37.

Calka, P. E. (2010) 'EFFECTS OF A 24-WEEK DEEP WATER AEROBIC TRAINING PROGRAM ON', 27(2), pp. 95-98.

Chu, K. S. et al. (2004) 'Water-based exercise for cardiovascular fitness in people with chronic stroke: A randomized controlled trial', Archives of Physical Medicine and Rehabilitation, 85(6), pp. 870874. doi: 10.1016/j.apmr.2003.11.001.

Costa, R. R. et al. (2018) 'Water-based aerobic training improves strength parameters and cardiorespiratory outcomes in elderly women', Experimental Gerontology. Elsevier Inc, 108, pp. 231-239. doi: 10.1016/j.exger.2018.04.022.

Deanna Westby, M. (2001) 'A health professional's guide to exercise prescription for people with arthritis: A review of aerobic fitness activities', Arthritis \& Rheumatism, 45(6), pp. 501-511. doi: 10.1002/1529-0131(200112)45:6<501::AID-ART375>3.0.CO;2-Y.

Deurenberg-Yap, Tan BY, Chew SK, Deurenberg P, V. S. W. (1999) Body Composition and Diet of Chinese, Malays and Indians in Singapore :, Asia Pacific Journal of Clinical Nutrition.

Dowdy, D. B. et al. (1985) 'Effects of aerobic dance on physical work capacity, cardiovascular function and body composition of middle-aged women', Research Quarterly for Exercise and Sport, 56(3), pp. 227-233. doi: 10.1080/02701367.1985.10605367.

Gaesser, G. A. and Rich, R. G. (1984) 'Effects of high-and low-intensity exercise training on aerobic capacity and blood lipids.', Medicine and science in sports and exercise, 16(3), pp. 269-274. 
Granath, A. B., Hellgren, M. S. E. and Gunnarsson, R. K. (2006) 'Water aerobics reduces sick leave due to low back pain during pregnancy', JOGNN - Journal of Obstetric, Gynecologic, and Neonatal Nursing, 35(4), pp. 465-471. doi: 10.1111/j.1552-6909.2006.00066.x.

Grimm, W. et al. (2003) 'The New England Journal of Medicine Downloaded from nejm.org at NCSU HUNT LIBRARY on May 27, 2014. For personal use only. No other uses without permission. From the NEJM Archive. Copyright (C) 2010 Massachusetts Medical Society. All rights reserved.', Circulation, 108(23), pp. 2883-2891. doi: 10.1161/01.CIR.0000100721.52503.85.

Helgerud, J. et al. (2007) 'Aerobic high-intensity intervals improve VO2max more than moderate training', Medicine and Science in Sports and Exercise, 39(4), pp. 665-671. doi: $10.1249 / \mathrm{mss} .0 \mathrm{~b} 013 \mathrm{e} 3180304570$.

Hoeger, W. W. . and Hoeger, S. A. (2011) Lifetime Physical Fitness and Wellness: A Personalized Program, 11th Edition. Wadsworth.

Hoeger, W. W. K. and Hoeger, S. A. (2009) Jump-start your personal journey to health with Integrated with Hoeger and Hoeger's text! Heads Up! Ifyou have an access card your text, don 't Log on to CengageNOW today! academic . cengage . com / cengagenow. Elizabeth. Edited by A. Lustig. Wadsworth: Yolanda Cossio.

Kell, R. T., Bell, G. and Quinney, A. (2001) 'Musculoskeletal fitness, health outcomes and quality of life (Kell, R.T., Bell, G. \& Quinney, A. -2001-)', 31(12), pp. 1-11.

Lee, J. et al. (2013) 'Aerobic exercise alone results in clinically significant weight loss for men and women: Midwest exercise trial 2', Obesity, 21(3), pp. E219-E228. doi: 10.1002/oby.20145.

Liu, M. W. et al. (2011) 'Effect of atoryastatin on airway remodeling and peroxisome proliferatoractivated receptor-gamma expression and its mechanism in asthmatic rats', Acta Anatomica Sinica, 42(3), pp. 361-366. doi: 10.3969/j.issn.0529-1356.2011.03.014.

Mackenzie, B. (2005) 101 Tests D'Évaluations.

Madhankumar, M. (2017) 'AQUA AEROBIC EXERCISE AND AEROBIC EXERCISE RESPONSES ON VO2 MAX RESPONSE AMONG COLLEGE MEN STUDENTS: EFFECT STUDY, 0, pp. 381-382.

Mahar, M. T. et al. (2011) 'Estimation of aerobic fitness from 20-m multistage shuttle run test performance', American Journal of Preventive Medicine. Elsevier Inc., 41(4 SUPPL. 2), pp. S117S123. doi: 10.1016/j.amepre.2011.07.008.

Mcrae, G. et al. (2012) 'Volume sangat rendah,-seluruh tubuh aerobik - pelatihan ketahanan meningkatkan kebugaran aerobik dan daya tahan otot pada wanita', 1131, pp. 1124-1131.

Mehrtash, M. et al. (2015) 'The effects of 6 months specific aerobic gymnastic training on motor abilities in 10 - 12 years old boys', Science of Gymnastics Journal, 7(1), pp. 51-60.

Nakata, Y. et al. (2005) 'Effects of aerobic exercise and obesity phenotype on abdominal fat reduction in response to weight loss', International Journal of Obesity, 29(10), pp. 1259-1266. doi: 10.1038/sj.ijo.0803013.

Palekar, T. J., Shah, P. A. and Kadam, M. R. (2018) 'Effect of Underwater Treadmill Training on Young Obese Adults', International Journal of Scientifc Research in Science \& Technology, 5(4), pp. 1487-1492.

Pescatello, S, L. et al. (2014) isi

Pinto, S. S. (2011) 'Cardiorespiratory and neuromuscular responses during water aerobics exercise performed with and without equipment', International Journal of Sports Medicine, 32(12), pp. 916923. doi: $10.1055 / \mathrm{s}-0031-1283176$.

Pollock, M. L. et al. (2018) 'of middle-aged men', Applied Physiology, 3, pp. 126-130.

Rump, P. et al. (2002) 'Body Composition and Cardiorespiratory Fitness Indicators in Prepubescent Boys and Girls', 2. 
Thompson, P. (2014) 'Benefits and Risks Associated with Physical Activity', ACSM's Guidelines For Exercise Testing and Prescription, p. 3.

Trajković, N. et al. (2016) 'Impact of gymnastics program on health-related fitness in adolescent pupils', Science of Gymnastics Journal, 8(2), pp. 157-166.

Tsai, H. C. (2011) 'Using weighted genetic programming to program squat wall strengths and tune associated formulas', Engineering Applications of Artificial Intelligence. Elsevier, 24(3), pp. 526-533. doi: 10.1016/j.engappai.2010.08.010.

Tsourlou T, Benik A, Dipla K, Zafeiridis A, K. S. (2006) 'The effects if a twenty-four-week aquatic trainig program on muscular strength performance in healthy elderly women [with consumer summary]', Journal of Strength \& Conditioning Research, 20(4), pp. 811-18.

Wang, T. J. et al. (2007) 'Effects of aquatic exercise on flexibility, strength and aerobic fitness in adults with osteoarthritis of the hip or knee', Journal of Advanced Nursing, 57(2), pp. 141-152. doi: $10.1111 / \mathrm{j} .1365-2648.2006 .04102 . x$.

Wenger, H. A. and Bell, G. J. (1986) 'The Interactions of Intensity, Frequency and Duration of', Sports Medicine, 3(5), pp. 346-356. doi: 10.2165/00007256-198603050-00004.

Williams, L. D. and Morton, A. R. (1986) 'Changes in selected cardiorespiratory responses to exercise and in body composition following a 12-week aerobic dance programme', Journal of Sports Sciences, 4(3), pp. 189-199. doi: 10.1080/02640418608732118.

$\mathrm{Xu}, \mathrm{R}$. Y. et al. (2018) 'Body mass index, waist circumference, body fat mass, and risk of developing hypertension in normal-weight children and adolescents', Nutrition, Metabolism and Cardiovascular Diseases, 28(10), pp. 1061-1066. doi: 10.1016/j.numecd.2018.05.015.

Yane, S. (2014) 'LENGAN DENGAN KEMAMPUAN SERVIS BAWAH BOLA VOLI PADA MAHASISWA PUTRA SEMESTER II STKIP-PGRI PONTIANAK', jurnal, 3(X 1), pp. 6573.

Yuriy, B. et al. (2014) 'Qualificational differences in the structure of archery training on different stages of Long-Term training', Journal of Physical Education and Sport, 14(3), pp. 426-430. doi: 10.7752/jpes.2014.03065.

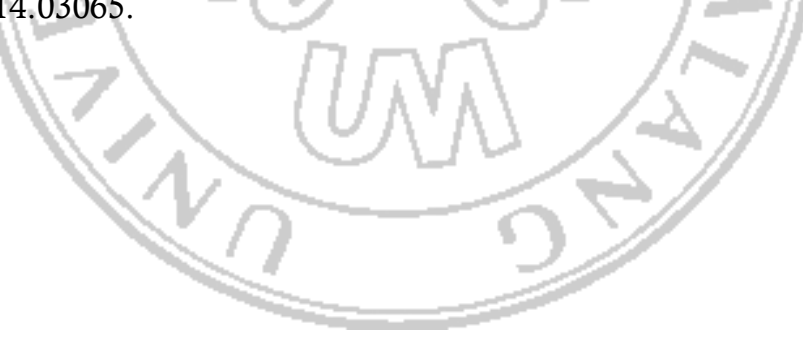

